\title{
BRIGAS DE FAMÍLIA E A DINÂMICA DO PARENTESCO ENTRE JUDEUS DO SURINAME
}

Thiago Niemeyer

Na varanda de sua casa em Paramaribo, um rabino sul-africano que reside no Suriname conversava comigo sobre a casualidade com a qual os conflitos eram tratados na comunidade judaica local. Para ele, isso implicava sérios riscos à existência dos judeus no país. O rabino, que acabara de chegar de San Antonio, no Texas, onde comandava uma comunidade ortodoxa, não via problema algum em que as pessoas brigassem; nos Estados Unidos elas o faziam tanto ou mais do que ali. O que o preocupava era a manutenção de certa frequência à sinagoga, que garantiria que a comunidade "funcionaria". Mesmo que determinadas pessoas brigassem ou ficassem cansadas de frequentar os serviços, deveria ser possível manter o templo sempre cheio, promovendo atividades "interessantes" para garantir uma "boa frequência".

Comecei por esse desvio um tanto anedótico porque meu ponto é precisamente investigar o quanto as brigas de família afetam a frequência aos serviços religiosos no país, geram "brigas" e reafirmam ou desautorizam determinadas parentelas. "Quando os judeus não brigam com os outros, brigam uns com os outros" - foi o que um senhor, com quem tinha mais contato, falou acerca da retórica de união aventada nas falas de alguns dos judeus da "comunidade". Frases como "somos todos uma comunidade" e "todos aqui buscam se ajudar", para ele, teriam valor apenas na medida em que "deveriam ser seguidas". Fatalmente, para meu interlocutor, os judeus irão brigar, pois é assim há séculos no país e, por sua experiência vivendo na Holanda, "em todo lugar".

Dessa maneira, pretendo discutir aqui a criação de afinidades tomando como pista principal "brigas" de família (mas também outros processos, como o compartilhamento de determinados espaços ou nomes). Baseado no material obtido ao longo de aproximadamente dez meses de trabalho de campo com as famílias judaicas do Suriname, procuro analisar a maneira como as brigas relacionam pessoas e quais são os seus efeitos concretos. Parece produtivo investigar também o vocabulário utilizado para descrever essas situações e a maneira como esses conflitos são entendidos pelos judeus do país. 
A história que me foi contada durante o período em que estive no país é a de que os judeus foram o primeiro grupo não autóctone a colonizar o Suriname. Sua chegada data do século XVII, quando, expulsos do Recife, um grupo de judeus, liderados por David Nassy, migrou para Caiena, na atual Guiana Francesa, depois para Barbados e, finalmente, se estabeleceu em Jodensavanne $^{1}$ (literalmente "savana judaica"), território autônomo concedido pelos então governantes ingleses. Lá, distantes da perseguição inquisitorial, alguns desses judeus, de origem sefardita ${ }^{2}$ portuguesa e, em menor escala, espanhola, se converteriam em plantocratas e senhores de escravos. Foi durante o século XVIII também que começaram a chegar judeus de origem asquenazita ${ }^{3}$ alto-germânica, falantes do iídiche, que fundaram sua própria comunidade, separada - e de relação diversas vezes conflituosa - da comunidade sefardita.

Os judeus do país se consideram remanescentes desses primeiros colonos - ou descendentes de famílias asquenazitas chegadas nos séculos seguintes - e congregam hoje na sinagoga de Neve Shalom, no centro histórico de Paramaribo. Atualmente, a população judaica no país é estimada entre 200 e 300 habitantes e, em 2004, as duas comunidades se uniram sob a rubrica de Surinaamse Joodse Gemeente ("Comunidade Judaica Surinamesa"), de denominação oficialmente liberal. ${ }^{4}$ A antiga sinagoga portuguesa foi alugada e hoje abriga uma lan house e loja de computadores, sendo o aluguel utilizado na manutenção do outro templo. Rivalidades permanecem, contudo: egressos da comunidade portuguesa de tendências mais "liberais" e da alto-germânica, mais "ortodoxa", divergem constantemente em torno de suas ideias sobre a judaicidade (jodendom) dos sujeitos e dos procedimentos litúrgicos. Durante os serviços do shabbat ${ }^{5}$ há a regra tácita, que opera como solução intermediária, de que metade dos assentos é mista — à maneira liberal - e a outra metade é exclusivamente masculina — ao modo ortodoxo.

Quando falo em "comunidade judaica" (joodse gemeente), utilizo o termo pelo qual os próprios judeus se denominam. Não tenho a pretensão de delimitar um grupo mais ou menos fechado definido por esse ou aquele traço étnico e/ ou identitário comum, no sentido de limitar o escopo de minha pesquisa. Ao contrário, procuro ser o mais fiel possível à forma pela qual os judeus do país tendem a representar a si próprios e a seus pares, rastreando as referências e os modos de fabricação da gemeente. Obviamente, a gemeente pode ser mais ou menos inclusiva, de acordo com uma lógica de situação que não pode ser formulada a priori. Sendo assim, nem sempre é possível afirmar com segurança quem é parte da gemeente e em que situação, já que seus limites estão a todo momento sendo redefinidos, de acordo com as formas bastante dinâmicas de negociar o que chamo (utilizando uma tradução inevitavelmente empobrecedora do termo Jewishness ou Jodendom) "judaicidade". 
Há modos diversos de compreender o que seja uma "comunidade", quando os interlocutores a mencionam como o grupo do qual fazem parte. É possível pensar nela como uma ordem dos fenômenos da vida social: o "indivíduo", enquanto unidade, pressuporia a participação em uma pluralidade. A pessoa como individual, necessariamente parte de um grupo mais amplo, é sempre "menos que o todo" (Strathern 1994:209). Noções como "indivíduo" e "sociedade" não serão utilizadas ao longo do trabalho e penso que, para tal, sejam necessárias algumas considerações "teóricas".

Outras figuras de pluralidade, como "identidade", também serão evitadas, em busca de outras noções possivelmente produtivas no diálogo com o material etnográfico. A própria natureza da digressão a seguir justifica a possível falta de profundidade ou a carência de considerações próprias: reflexões originais e ensaios bibliográficos de muito maior fôlego foram produzidos nas duas últimas décadas, todos buscando rediscutir a dicotomia indivíduo/sociedade como única possibilidade de entendimento dos coletivos humanos. Em The fractal person, Roy Wagner chama a atenção para a natureza ideal implicada na distribuição desses conceitos:

A oposição entre indivíduo e sociedade, produto da jurisprudência e da ideologia política ocidentais, não só coincide com a hegemonia do pensamento "social", como é idêntica a ele. Ela se baseia na noção necessariamente ideal, e praticamente irrealizável, do "conceito de social", bem como na noção necessariamente substantiva, física e material da pessoa como objeto (Wagner 1991:84).

Se não entendermos "comunidade" ou "família" como subsistema da "sociedade" (cf. Strathern 1994), é possível descrevê-las prestando atenção "ao modo como se tornam operacionalizadas como artefatos manipuláveis e utilizáveis nas buscas das pessoas por seus interesses e em sua construção de relacionamentos" (Strathern 1996). A comunidade é feita de parentesco e ancestralidade. Quando perguntamos a um judeu do que ela se trata, a chance de que a resposta seja "um grupo de famílias" é bastante grande. Pode-se esperar outras explicações, mas nunca ouvi uma que excluísse a linguagem da família e do parentesco.

\section{As "brigas de família"}

Voltando às "brigas de família", é justamente por seu potencial em relacionar pessoas que chamo a atenção para as reflexões de Carsten (2004) em After kinship acerca da noção de "relacionalidade" como alternativa às reflexões 
clássicas sobre parentesco. Essa "relacionalidade" (ou relatedness) implica um enfoque nas relações que nos obriga a entender o que é "ser parente" para além das categorias preestabelecidas do parentesco ocidental, amplamente baseado em ideias de consanguinidade. Determinados espaços, como a casa, nos permitiriam analisar uma dimensão processual do parentesco, na qual este é constantemente produzido. ${ }^{6}$ Em sua experiência etnográfica com comunidades de pescadores malaios, a coabitação implicava a inserção dos sujeitos em um ambiente de trocas que relaciona e cria parentes, permitindo que se observasse, não só o domínio das formas, mas também um parentesco "feito".

Sua reflexão acerca do espaço da casa como criadora de afinidades é tributária da noção de Lévi-Strauss de société à maison, como a própria Carsten destaca na coletânea que editou com Stephen Hugh-Jones em 1995, intitulada About the house: Lévi-Strauss and beyond. Sua visão, contudo, procura explorar de maneira crítica o rendimento da noção de Lévi-Strauss afora o das sociedades para as quais ele a pensou. Nessas sociedades, para Lévi-Strauss, uma casa é "uma pessoa moral que possui uma propriedade feita de riqueza material e imaterial que se perpetua através de transmissão de seu nome por uma linha real ou imaginária, considerada legítima enquanto essa continuidade possa se expressar na linguagem do parentesco ou da afinidade e, mais comumente, ambos" (Lévi-Strauss 1982:174). Trata-se de reconhecer, dessa forma, a "natureza processual tanto da construção da casa quanto das relações de parentesco" (Carsten 2004:44).

O termo "briga" (vechten/familievette) é empregado por meus interlocutores para descrever um ambiente de hostilidade entre pessoas ou grupos de pessoas. O uso do termo é bastante amplo, e as hostilidades podem ser abertas ou não. As duas "comunidades", assim, vivem "brigando" desde que se uniram, e já brigavam antes. Um imbróglio judicial que presenciei no campo sobre a venda de um terreno, por exemplo, ao envolver afastamento de grupos de pessoas, também é uma "briga". Nesse caso, entretanto, trata-se de hostilidades abertas, e não veladas.

As "brigas" (vechten) podem envolver "famílias" (gezinnen) ou apenas as "pessoas". O segundo caso é menos grave e compreende a maior parte das "brigas". É comum destacar que essa ou aquela briga é "apenas uma questão pessoal", para sinalizar que não se trata de uma "briga de família". Dadas as tensões latentes, qualquer "briga" pode se tornar uma "briga de família", na opinião de interlocutores. A agressão em uma "briga de família", embora normalmente seja mais grave do que nas "brigas" corriqueiras (que envolvem apenas as "pessoas"), não difere em princípio de uma agressão qualquer. Muitas vezes são a manifestação de uma tensão latente, e a 
agressão, por menor que pareça, é apenas o estopim para a manifestação do descontentamento de um partido em relação ao outro. Esses partidos são, quase invariavelmente, divididos em "famílias".

É possível que uma pessoa da família $\mathrm{A}_{1}^{7}$ que está em uma "briga" com a família $\mathrm{B}$, "tome partido" da segunda. As histórias que ouvi a esse respeito, no entanto, sempre relacionam a pessoa que está alinhada com outra família a uma ancestralidade diferente: pode-se, para efeito da "briga", dizer que ela estaria agindo como alguém da família C (a de sua mãe, de sua avó etc.), ou que, para ela, essa é apenas uma "briga pessoal". É comum listar os motivos práticos que levam alguém a fazer isso - perda de dinheiro, propriedades, questões relativas a negócios etc. — ou mesmo argumentações que apelam à racionalidade daquele que "briga": "ele não levou isso como algo 'familiar'"', "ele preferiu agir com a razão" etc. Enfatiza-se, em geral, que a pessoa não estaria colocando a unidade familiar em risco, e esta retórica, por mais contestável que seja, só foi refutada, em minha experiência, no contato com os jovens. A ambos os lados envolvidos na "briga" parece interessar a manutenção dessa retórica: a família do dissidente busca ressaltar a "união" de sua "família" e a que recebe seu apoio evita acusá-lo de estar indo "contra a sua família", o que implicaria, em última instância, "trair seu sangue".

É sempre possível, contudo, que alguém resolva alinhar-se voluntariamente à(s) outra(s) contra sua própria família. Conversando com meus interlocutores sobre essa possibilidade, ouvi falar de casos em que isso ocorreu. É importante notar que "brigas na família", as "brigas internas", são comuns e, se são vistas como ameaça à unidade familiar, não são entendidas como uma "traição". No caso de unir-se à outra família contra a sua, alguns informantes sugeriram que, se acontecesse com eles, o membro do grupo que fizesse isso não seria "judeu" ou "da família". Ser judeu no Suriname é, sobretudo, enfatizar certa ancestralidade sobre outra, e o expediente aventado por meus interlocutores seria o de considerar que alguém optou por destacar outra ancestralidade. Um exemplo concreto me foi dado, em forma de símile sociológico, utilizando pessoas com as quais eu convivia:

[...] se X [membro da família A] resolvesse ficar do lado da família B em uma "briga" que não tem nada a ver com ele, falando mal da sua família, dizendo que ela não presta, é porque X é indiano, e não judeu, entendeu? Ele não é da família de verdade. Por que ele iria brigar com a sua família só para falar mal dela?

Não se admite, dessa forma, que alguém possa ir contra sua família sem interesses concretos. Caso isso aconteça, o expediente utilizado no entendimento de uma situação como esta é destacar que a pessoa optou 
por uma ancestralidade não judaica: não parece haver judeus que não tenham descendentes não judeus e, caso haja, pode-se enfatizar que a pessoa em questão optou por tomar o lado de outra família que não aquela com a qual ele se identifica. Este caso, no entanto, foi visto como absolutamente distante e hipotético quando levantado junto a um interlocutor: ele não conseguiu imaginar alguém 100\% judeu e, ainda por cima, disposto a "trair o seu sangue". Sua resposta foi: "não sei, acho que não... faz sentido, mas é impossível, ou quase impossível... mas não". Portanto, uma possibilidade estrutural de direito, mas não de fato.

Esta situação ilustra a ação combinada entre possibilidade e escolha, constitutiva do que é "ser judeu" no país. Analogamente, os crioulos de Nova Orleans também optam por se identificar como crioulos quando, na grande maioria dos casos, como mostrou Dominguez (1986), poderiam optar por outras ascendências:

Crioulos de cor podem reconhecer muito mais as misturas do que os Crioulos brancos. Mas a realidade da herança mista tem as mesmas implicações para ambos: autoidentificação como Crioulo implica um elemento de escolha de filiação a um grupo e não é simplesmente o corolário da ancestralidade. Alguém escolhe ressaltar uma conexão com um ancestral em particular no lugar de outras possíveis (Dominguez 1986:188).

"Brigar na família" é normal e, até certo ponto, aceitável. Embora as famílias sejam entendidas como unidades harmônicas, existe o sentido de que é inevitável que dentro delas ocorram "brigas". Pode-se querer mais "poder" (macht), entendido aqui como maior participação em processos decisórios ou reconhecimento como alguém com direito de falar em nome da família, ou pode haver razões aventadas como "práticas": heranças, dinheiro e brigas com parentes por afinidade, como sogras, cunhados etc.

Deve-se evitar "brigar na família", já que a briga coloca em jogo uma unidade entendida com primordialmente estável. Quando se "briga na família", é importante que a briga "fique na família": uma família que briga é vista como uma família menos harmoniosa do que as demais. Reconhecendo-se, no entanto, a inviabilidade de não "brigar" com familiares, vários interlocutores enfatizaram a importância da discrição e de um código que pressupõe que as brigas devam ser resolvidas sem envolver outras pessoas. "O que acontece na família, fica na família".

Ao mencionar este ditado, contudo, o interlocutor pode fazê-lo de duas maneiras distintas: ao se entender "família" como núcleo familiar (pai, mãe, filhos), diz respeito a uma sabedoria mais amplamente difundida; ao se falar 
em "família" no sentido de "nome", refere-se a uma ética específica utilizada para resolver problemas minimizando o estremecimento nas relações entre os diversos membros da "família" e mantendo o "nome" intocado. Há um trânsito constante entre os sentidos da palavra "família", e esse lema, por exemplo, vale para os dois. As implicações aventadas para o vazamento de uma briga de família, contudo, são diferentes quando se fala em núcleo familiar e na família como "nome": no primeiro, trata-se de evitar que estranhos saibam de problemas que, apesar de "toda família ter" (como alcoolismo, dívidas, uma gravidez indesejada ou vício em determinada droga), "não diz respeito aos outros". No segundo - o vazamento de uma "briga na família" - estaria em xeque a união familiar, sua judaicidade, a capacidade de resolver seus próprios problemas etc. A natureza dos problemas, como procurei descrever, tende a ser diferente.

Apesar do fato de os "judeus brigarem" ser tomado como um dado por grande parte dos meus interlocutores - a despeito da retórica de união invariavelmente acionada em um primeiro contato - espera-se que eles saibam resolver seus conflitos. As "brigas" não devem colocar em jogo o "futuro" da "comunidade" e aquelas consideradas possivelmente daninhas neste sentido tendem a ser largamente reprovadas: é preciso que se tenha uma "razão" para "brigar". Essa necessidade é explicada em função de que, quando há uma "razão" para a briga, há espaço para o estabelecimento de uma trégua. Em um plano ideal, a "briga" não deve envolver os "outros" (pessoas ou famílias), entendidos aqui como partes não implicadas. A "desagregação" pela qual a comunidade estaria passando derivaria, assim, da falta de "união", promovida por constantes "brigas" sem propósito. O fenômeno relativamente recente da emigração, especialmente para a Holanda, tem o "cansaço de brigar" diversas vezes aventado como uma de suas razões. O processo decisório que envolve o abandono do país passaria, dessa forma, pela falta de "união" e a "desintegração" da comunidade judaica, que fariam com que não valesse a pena para os que partiram a permanência no país; em geral, essas razões são elencadas ao lado de outras, como falta de empregos, instituições de estudo etc.

Os judeus que deixaram o país continuam sendo contados, em contextos específicos, como membros da "comunidade". Seu poder decisório é sempre colocado em xeque pelo fato de eles "terem ido embora", mas membros respeitados podem ser procurados para conselhos, e a vida dos que vivem na antiga metrópole é assunto cotidiano, já que eles fazem parte da "família" ou da "comunidade". Em sua etnografia sobre sindicatos de trabalhadores rurais na zona da mata de Minas Gerais, John Comerford observa que: 
[...] é importante notar também que o fluxo "para fora" e eventualmente de volta "para dentro" das localidades é acompanhado com cuidado e interesse pelo público da localidade, de modo que deslocar-se para fora da localidade não significa imediata ou necessariamente sair do campo de observação/informação/julgamento do círculo social ao qual pertence a família. As pessoas sabem para onde foram seus parentes e os parentes dos outros, avaliam seus sucessos, fracassos, dramas, retornos. [...] Dessas pessoas e famílias em lugares distantes cuja localização a cada momento se acompanha com interesse, se fala com orgulho, desdém, tristeza, maldade (Comerford 2003:43-44).

Há também os judeus que retornam, e aqui se destacam dois grupos distintos: os que "voltam jovens", depois de estudarem no exterior, de experiências de trabalho frustradas ou de simplesmente não se adaptarem a outro país, em geral a Holanda, e os que retornam "já velhos", em geral depois de terem trabalhado a vida inteira fora e acumulado dinheiro suficiente para se aposentarem em seu país natal. A Holanda corresponde, como na sociedade surinamesa de forma mais ampla, ao destino preferencial para emigração (até porque alguns de meus interlocutores eram cidadãos holandeses), mas há pessoas indo viver nas Antilhas, nos Estados Unidos, na Austrália ou em Israel, entre outros. Os que retornam "jovens", em geral não são alvo das mesmas críticas dirigidas àqueles que o fazem em um momento mais tardio de suas vidas: estes são alvo de comentários, por vezes desdenhosos, de que não conhecem mais a realidade do país, a "comunidade", ou que simplesmente a "comunidade mudou muito desde que eles foram embora".

Os que "voltam velhos" encontram maior resistência na participação de processos decisórios que envolvam a "comunidade". Embora haja um senhor "retornado" no comitê da Sinagoga, sua influência é limitada pelo fato de existir sempre a possibilidade de que, por ter passado sua vida inteira fora do país, suas decisões ou propostas sejam desautorizadas. Os que "ficaram" (depois da independência e da guerra civil) alegam ter maior conhecimento sobre a "comunidade", já que puderam acompanhar o seu percurso. Além disso, sendo um problema para os judeus a possibilidade de sua extinção no país, os emigrantes corroborariam para o desaparecimento da "comunidade", já que não podem participar, efetivamente, de sua vida cotidiana.

Os judeus que vivem fora do país (mais uma vez, especialmente na Holanda), contudo, não estão excluídos do que Comerford chamou de "mapeamentos": sua vida é alvo de intensa curiosidade, o contato com "familiares" permanece forte, por vezes envolvendo envio de dinheiro, e espera-se, na mesma medida em que se permite, que os mais "velhos" intervenham em impasse e "brigas de família". Pelo que pude perceber em meu contato 
com famílias judaico-surinamesas na Holanda, a recíproca é, de certa forma verdadeira. Há uma enorme curiosidade sobre o que se passa na "comunidade": desde questões familiares até a frequência aos serviços religiosos, as pessoas estão em constante comunicação com suas famílias no Suriname.

É possível, no entanto, abandonar esse circuito de informações e curiosidades, e isto se mostra particularmente comum em gerações mais novas, pouco interessadas em questões referentes à "comunidade". Um interlocutor muito jovem, levado para a Holanda com meses de idade, destacou que este tipo de assunto interessava à sua mãe e que, embora já tenha visitado o Suriname e ficado feliz em conhecer sua família e sua "cultura", não se interessa por estas questões. Em sua opinião, tratava-se além disso, de "fofocas" (roddel), e ele relatou ter ficado descontente quando parentes no Suriname quiseram saber "demais" sobre sua vida e problemas pessoais que ele considerava íntimos. O episódio foi interpretado como uma "invasão de privacidade... eu não quero saber da vida deles, só quero que eles estejam bem. Então, não gosto que fiquem querendo saber da minha 'vida pessoal' ${ }^{\prime \prime}$.

Desse modo, é perfeitamente possível "sair da comunidade", no sentido de se afastar do circuito de informações cujos membros são simultaneamente objeto de curiosidade e curiosos. Muitos judeus que conheci enfatizam que "ser judeu" foi uma "escolha": poderiam ser indianos, chineses etc. Alguém que pare de frequentar os círculos sociais das famílias judaicas, a sinagoga (mesmo nas datas festivas, quando ela costuma ficar bastante cheia), que pare de buscar informações acerca de outras pessoas e famílias, ou comece a se relacionar excessivamente com o lado não judeu de sua família pode ser rapidamente identificado como "não judeu". Caso a pessoa não tenha nascido de ventre judaico, e a opção por "ser judeu" tiver sido fruto de uma "escolha" que deve ser reafirmada em face das constantes evocações das regras da Hallakah, ${ }^{8}$ o processo é ainda mais fácil.

Uma "jovem" que conheci durante uma de minhas viagens, nas reuniões de quinta-feira, havia "perdido o interesse" pelo judaísmo, segundo alguns interlocutores. Ainda que a própria jovem continuasse a se considerar judia ela era filha de uma mãe identificada como "crioula" e de um pai dougla, ${ }^{9}$ filho de um judeu, mas frequentador de uma denominação protestante sua "falta de interesse" fazia com que a maior parte de meus interlocutores, mesmo os que aceitavam sua judaicidade, em função de sua inclinação liberal, não a considerassem mais judia, já que "ser judeu" (especialmente neste caso) era uma escolha. 
É possível optar, em uma "briga", pelo lado contrário àquele com que sua família (ou a maior parte dela) se alinhou. Alguns interlocutores descreveram, em querelas mais ou menos graves do passado, situações em que o "coração" apoiava um familiar, mas a "razão" (encarnada em um dever de ofício ou princípio moral) obrigava-os a apoiar a outra família, ou abster-se da questão. A despeito da retórica de "união", as famílias não são, assim, partidos a priori em determinada contenda. Cada vez em que há uma "briga" existe uma lógica que implica tomar lado, ou "manter-se neutro"; a "família" exerce papel fundamental na escolha do lado a ser tomado, mas não impede que se tome o partido de quem está "brigando" com sua família.

Há, entretanto, um preço a ser pago ao se ir contra a própria "família", mesmo que as razões sejam as mais justificáveis e compreensíveis. É possível esperar retaliações, até quando os envolvidos na briga já tenham "entendido" seu posicionamento contrário ou neutro ao da maioria da "família". A rede de solidariedade a partir da qual se espera que os familiares se ajudem pode tornar-se menos acessível para aquele que não apoiou sua família em determinada "briga" (ainda que a retórica seja aceitável, como, por exemplo, o "dever de ofício" de certos funcionários públicos ou agentes do Estado). Ironicamente, a falta de apoio (ou mesmo a "neutralidade") é capaz de ser aventada como razão futura para um eventual apoio a outro "lado", ou como justificativa para manter-se neutro.

Permanecer "neutro" implica, como o nome sugere, não tomar partido deste ou daquele. Essa atitude, em primeiro lugar, precisa de uma "desculpa aceitável" que permita que a pessoa se mostre solidária à família, ao mesmo tempo em que não se envolve no conflito. Outra maneira de se manter "neutro", segundo meus interlocutores, é buscando se afastar, ou mantendo-se incomunicável. Um deles, em uma de minhas viagens, comemorava o fato de estar visitando a família na Holanda durante uma briga familiar que ele considerava frívola, mas que o obrigaria a "tomar o lado" de sua família. Dessa maneira, sempre que a história é rememorada, ele nunca é citado. Caso seja, tudo de que se lembra é que ele estava "fora" e não pôde ajudar sua família (pressupõe-se, no mais das vezes, que ele o faria).

Evitar os seus "familiares" alegando ter compromissos de trabalho, questões de ordem pessoal (que se pretenda que sejam acreditadas, devem ser explicadas) ou de saúde também requer justificativas aceitáveis, no sentido de minimizar ou anular o risco de desgaste familiar. Quando uma "briga" começa, e há o consenso de que ela envolve a família, uma rede de informações é acionada no sentido de deixar os familiares cientes do que se passa. Telefonemas, visitas para um café, uso de skype (no caso 
de parentes na Holanda) e outras ferramentas eletrônicas, como redes sociais (especialmente no caso dos mais jovens), são acionadas no sentido de descrever a "briga" e angariar o apoio familiar esperado, mesmo que em forma de simpatia.

É importante destacar que os parentes que vivem na Holanda são entendidos como mais próximos, no sentido de mais capazes de atuar e intervir em questões familiares, do que os que vivem em outras partes do mundo. Aqueles que residem nas Antilhas, especialmente em Curaçao, são considerados relativamente acessíveis, ainda que menos do que os holandeses: para efeito de questões familiares, os que vivem nos Estados Unidos, em Israel ou na Austrália, por exemplo, são considerados quase "fora do mapa", não por sua acessibilidade, mas por uma pressuposição de que eles tenham perdido, ainda que temporariamente, o conhecimento de causa no que tange aos assuntos da comunidade.

Do ponto de vista sociológico, embora os interlocutores descrevam as brigas quase unicamente através do idioma do parentesco, este é apenas mais um dos componentes que envolvem o ato de "brigar". Há razões, tanto práticas quanto emocionais, que transcendem as "famílias", ainda que os conflitos sejam quase sempre colocados nestes termos. Este fato não é puramente "retórica": envolve efeitos positivos na realidade, já que muitas vezes se adere a um dos lados simplesmente por se tratar de "sua família". É comum, na fala de interlocutores, a sugestão de que a manifestação de apoio se deu apenas por se tratar de um familiar. A indisposição desnecessária com outros membros da comunidade raramente é desejada.

Por mais multilaterais que os conflitos sejam, eles são sempre entendidos como se tivessem dois lados: o lado A, que envolve tais e tais famílias e o lado B, que envolve outras famílias, além dos dissidentes. Ainda que as motivações para entrar em uma "briga" sejam as mais diversas possíveis, são aventados dois objetivos: o lado A pretende fazer determinada coisa, e o lado B, outra. Na fala dos interlocutores, percebe-se que há desde a pura vontade de "brigar" com pessoas das quais não se gosta até questões financeiras delicadas. Pode haver também ressentimento em função de uma briga anterior ou intenção de ganhar influência ou vantagens com pessoas específicas, de forma completamente alheia à lógica familiar (alguns membros da comunidade são empresários ricos, oficiais do governo etc.), de modo que o motivo para entrar ativamente em uma briga seja um empréstimo ou um novo emprego, por exemplo. Embora tudo isso possa ser interpretado como "fofoca" (roddel), a estética da disputa supõe dois lados, em geral encabeçados por duas famílias e "famílias amigas", "brigando" em torno de uma questão central. 


\section{"Dentro e fora" das famílias}

Na seção anterior, mencionei o fato de meus interlocutores distinguirem "briga entre famílias" de "briga na família", sendo a primeira entre "famílias" distintas e a segunda no seio de uma mesma família-nome ou núcleo familiar. Todo esse vocabulário supõe que as famílias tenham um "dentro" e um "fora". A experiência etnográfica mostra que essa oposição é antes relacional do que dada; com o parentesco sendo feito constantemente a partir de "brigas" ou compartilhamento de nomes de família comuns (ainda que não haja compartilhamento de substância), não é possível conhecer o "dentro" e o "fora" das "famílias" a priori. Outro complicador é o fato de "família" ter sentidos diversos, o que faz com que o termo "briga em família" possa ser utilizado para descrever tanto violência doméstica quanto uma querela entre descendentes de um mesmo ancestral, portadores do mesmo nome. Não obstante, meus interlocutores tratam a família como portadora de um "dentro" e um "fora" - certas brigas devem ser mantidas "fora da família". Uma primeira maneira de acessar essa distinção é buscando entender o que se considera "dado" e o que se toma como "construído" nesse contexto etnográfico. Aí residem as primeiras pistas das sempre movediças fronteiras do "dentro" e "fora" do artefato família.

As famílias nucleares são entendidas como "dadas", mas em intensidades diferentes. A díade mãe e filho é particularmente naturalizada; uma mãe que se distancia do filho é inevitavelmente alguém que "abandonou a família". No caso paterno, muito mais comum, o abandono do núcleo familiar destrói gradualmente a afinidade, retirando o homem, pouco a pouco, do circuito de relações da família de sua esposa; de imediato ele deixa de ser contado como "parente" pela família da esposa, embora se entenda que sua relação ainda implique obrigações (como ajudar no sustento do filho), quase sempre baseadas em metáforas de substância: a noção de que o pai "concebeu o filho", que o filho é "sua carne e seu sangue" etc.

Em relação ao filho, o pai que abandona a casa e evita os contatos com sua antiga família, mesmo sendo considerado alguém que partilha o "sangue" do filho, pode ser gradualmente tido como um não parente, já que se afasta em demasia do conjunto de relações que constituem o que meus interlocutores chamam "paternidade" (vaderschap). A opção pelo nome materno, embora diversas vezes aluda à vontade de afirmar uma ancestralidade judaica, pode também destacar o distanciamento do pai de um conjunto de obrigações implicadas na noção de "paternidade", até o ponto em que a substância é tudo o que resta da relação pai e filho: 
- Meu pai, meu pai não vale a pena falar dele, a única coisa que ele fez foi me fazer [...] Ele tratava minha mãe como se fosse lixo, e a mim também. Sempre fomos muito ricos, mas ele tinha tantas $\underline{\text { buitenvrouwen }}{ }^{10}$ que mal sobrava dinheiro para nos sustentar [...] quer dizer, não me faltava comida, mas eu era o único da "família" que não podia fazer faculdade. Isso era em 1969, mas meu pai nunca estava em casa, e estava tão preocupado com as suas mulheres que quando chegava lá, bêbado, era para arrumar um motivo para me bater. Depois ele foi embora de casa, e ninguém nunca sabia onde ele estava. Eu fui o único dos $\mathrm{C}$ a trabalhar com 16 anos... Donald B me arrumou um emprego no escritório comercial dele no centro. Acabei conseguindo ir para a faculdade, porque meus parentes fizeram um fundo, viram o meu esforço [...] fiquei triste em deixar minha mãe aqui, mas ela pediu para eu fazer isso. Sempre estava em contato com ela de lá (da Holanda), mas nunca mais falei com meu pai.

Para meu interlocutor, seu pai o havia apenas gerado. Formalmente, tratava-se de seu pai, mas do ponto de vista das obrigações que a paternidade implica, ele estava excluído da rede de relações que constituem a noção idealizada do núcleo familiar. Embora provesse a casa com o mínimo, não deixando meu interlocutor e sua mãe passarem fome, gastava seu dinheiro com outras mulheres e "famílias", nunca estava em casa e tratava-os de maneira agressiva e distante. Do ponto de vista processual, para ele, o que os mantinha minimamente ligados era o ato de tê-lo gerado, já que seu pai "o fez". Além disso, ele tem "seu sangue"; ainda que faça sempre questão de frisar as "qualidades" do "sangue" de sua mãe, precisamente as que teria herdado, como "honestidade", "obstinação" e "dedicação à família". ${ }^{11}$ Não raro menciona, entretanto, em rodas de amigos, que herdou de seu pai "um jeito para lidar com mulheres", no sentido de possuir habilidade para seduzi-las. Este senhor, já casado algumas vezes — sempre com mulheres que ele qualifica como "bonitas" — está casado com uma mulher trinta anos mais nova, graças, segundo ele, às habilidades herdadas de seu pai.

A palavra "família" aqui também é usada indistintamente para designar dois conjuntos de relações completamente distintos. Ao mencionar o descaso de seu pai com as obrigações inerentes ao ofício da "paternidade", ele o faz no sentido de núcleo familiar. Aludindo às buitenvrouwen de seu pai e aos filhos que tinha com elas, também alude à família no sentido nuclear, embora os considere "ilegítimos" por uma série de razões. Quando menciona que não pôde, em oposição a seus "familiares", ir para a faculdade ao concluir a escola, estes familiares têm o sentido amplo de "parentes", tanto paternos quanto maternos, consanguíneos e afins. Por fim, explicando que foi o único da família C a trabalhar desde os 16 anos, utiliza o termo "família" no sentido 
de "nome". Buitenvrouw deve ser entendido como relacional: um interlocutor cuja mãe era apontada por alguns como fruto de um relacionamento entre um judeu e sua amante; no entanto, não considerava que sua avó fosse uma buitenvrouw, mas sim "esposa" de seu avô. Ele lembra com carinho do avô na infância e se refere à avó como a "segunda mulher de meu avô".

Voltando à concepção nativa de "dado" e "construído", a substância "sangue" implica a herança de qualidades, pelo menos em potencial. Aqueles unidos pelo mesmo "sangue" são destacados como "parentes", a despeito do que possa acontecer. A noção de parente, aqui, não representa necessariamente obrigações mútuas, mas o compartilhamento de "substância". Dessa forma, irmãos, filhos, netos dos mesmos avós, sobrinhos e primos em primeiro grau serão sempre considerados "parentes". Os filhos desses primos/primas, assim como o parentesco deles com os seus filhos, são referidos como "primos". É importante notar que a língua holandesa utiliza a mesma palavra para "primo/ prima" e "sobrinho/sobrinha", respectivamente, neef e nicht. Nesse sentido, os parentes de "sangue" são seus irmãos ( $\underline{\text { broers }}, \underline{\text { zusters }})$, pai, mãe e avós (vader, moeder, oma e opa), filhos e filhas (zonen e dochters), além do uso amplo do termo "primos" para descrever desde sobrinhos até primos em terceiro grau.

Para parentes mais distantes, pode-se utilizar o termo "primos" ou "parentes". Mas o "sangue", em geral, não mais obriga a considerá-los membros da família. Não raro, contudo, esses "parentes" são incluídos em relações familiares, especialmente quando têm o mesmo nome ou clamam ancestralidade pela mesma família-nome (ex: Arnold Wereldens é judeu por ser da família C, logo, é parente de Anthony C). Muitas vezes o espaço da sinagoga é onde alguns desses judeus recém-aparentados se conhecem e estreitam suas relações. Espera-se desde o apoio em situações de "briga" até a inclusão em redes de solidariedade que procuram ajudar a estabelecer parentes no exterior, arrumar empregos ou emprestar dinheiro em caso de necessidade. Dessa forma, passam a ser reconhecidos como "familiares" e se criam relações de obrigação mútua, assim como uma maior intimidade, no sentido de visitas ocasionais e convivência mais estreita entre os filhos, que passam a ser criados como "primos".

Muitos "primos" de interlocutores são amigos próximos, e contam histórias de como seus pais se descobriram parentes no espaço do Mahamad $^{12}$ ou a partir de pesquisas genealógicas. Alguns deles, note-se, são considerados parentes próximos, mas sua ancestralidade comum diverge há até seis gerações, de acordo com suas stambomen. ${ }^{13} \mathrm{Um}$ interlocutor disse ter um parente muito próximo em Curaçao, do qual guarda excelentes memórias de infância; ambos são judeus da família D. Contudo, a chegada do primeiro ancestral de seu primo data do século XVIII, quando da construção de um hospital 
em Paramaribo, enquanto seu ancestral mais antigo, com o mesmo nome D, chegara sessenta anos mais cedo, ainda em Jodensavanne. Trata-se, assim, de dois troncos absolutamente distintos, não havendo consanguinidade alguma, $\mathrm{e}$ vale ressaltar que D é um sobrenome comum nas listas judaicas de imigrantes dos séculos anteriores. Não obstante, seu "primo" é um "parente próximo", membro da mesma família-nome. Seus filhos, que têm aproximadamente a mesma idade (ambos casados e um deles já com filhos) são grandes amigos e também "primos" e foram criados juntos, como "irmãos".

Meu interlocutor em momento algum referiu-se ao parentesco entre ele e seu "primo" como "fictício". Inclusive, ao mencionar algumas qualidades que a família D possuía, vindas do "sangue", incluía seu "primo". A distinção entre afinidade e consanguinidade não faz sentido aqui; há apenas relações, embora meus interlocutores configurem, eles próprios, uma distinção entre parentes "de sangue/nome" e aqueles que casaram na família. Supor que esta oposição seja como a nossa, no entanto, é absolutamente improdutivo, e impediria um entendimento de como as categorias de relacionalidade são construídas no plano processual. Seríamos forçados a entender que o caso dos primos D é uma forma de parentesco fictício. Tratando-se as famílias D de famílias homônimas, seria natural considerá-las D1 e D2 e entender que há um parentesco fictício que une membros das duas. Entretanto, isto iria contra a noção de parentesco de meus interlocutores, que não operam tal distinção. O exemplo de Carsten sobre as relações do uso da linguagem do parentesco em uma comunidade gay de São Francisco, retirado da etnografia de Weston, sugere "categorizar essas amizades como parentesco 'fictício', em oposição a um parentesco 'real' derivado da procriação sexual no qual essas amizades são vistas como tão reais quanto qualquer parentesco" (Carsten 2004:146).

É importante destacar que "sangue" (bloed) e "nome" (naam) têm conotações parecidas. Tendo os membros da mesma família-nome qualidades similares, herdadas de seus ancestrais, o "nome" desafia, em certa medida, as divisões clássicas que pressupõem a oposição entre um parentesco baseado na reprodução sexual e outro fictício. Isto não quer dizer que, do ponto de vista nativo, não haja relações de parentesco consideradas "não naturais"; padrastos e madrastas, quando queridos, são referidos "como um pai/uma mãe", no sentido de que, a despeito de não haver um parentesco outro além daquele implicado no casamento, o(a) enteado(a) considera a pessoa em questão "um parente de verdade". A recíproca é verdadeira para o caso de padrastos/madrastas especialmente apegados(as) aos(às) filhos(as) de seus(suas) esposos(as) e companheiros(as). Todos, ao fim e ao cabo, são "família"; a maior parte dos interlocutores traça, contudo, uma diferença entre família "de sangue" (e, por extensão, "nome") e "parentes" que se uniram à família por casamento. 


\section{Conflitos, trégua e novas formas}

Há toda uma rede de comunicações (que pode envolver parentes na Holanda) no sentido de avaliar quando determinados "parâmetros" foram violados. Um de meus interlocutores, com o qual tinha certa proximidade, certa vez me pediu licença para ligar para seu tio na Holanda, pois ele saberia resolver uma situação que parecia estar ficando "fora de controle" (uit de hand). A questão envolvia a maneira de calibrar seu próprio comportamento diante de pessoas das quais ele não gostava: parecia, para ele, que algo "drástico" poderia acontecer se um dos lados não "abaixasse as armas". Seu tio, no entanto, poderia lhe dizer se aquele era ou não o momento "para brigar". A partir de uma descrição minuciosa da situação e dos atores envolvidos, apresentar-lhe-ia os possíveis desfechos e aconselharia se valeria a pena, ou não, brigar ou tentar contemporizar a situação, ainda que esta última saída acarretasse a necessidade de "não ser orgulhoso" (wees niet trots op).

Seu tio, mesmo não vivendo mais no país, morou por muitos anos lá; é muito experiente e viu a "comunidade", de alguma forma, sobreviver, mesmo que os conflitos tenham muitas vezes ditado o rumo da convivência cotidiana (especialmente após a junção das sinagogas). Sabe negociar, conhece o momento de brigar e o momento de engolir o orgulho, é considerado mais capaz de estabelecer o parâmetro no qual esse ou aquele comportamento deve ser acionado. Nas palavras de meu interlocutor,

[...] meu tio logo vai voltar pra cá, ele sabe a hora de brigar, de fazer as pazes [...] lá [na Holanda] conseguiu um dinheiro bom, mas agora virá para casa. Eu fico mais tranquilo ligando para ele, porque todo mundo respeita ele [...] se hoje ele me diz para não brigar, mesmo que essas pessoas estejam se gabando mesmo sem ter nada, isso não mexe no meu orgulho. Eu deixo eles lá, depois eu falo a verdade e eles não aparecem mais na sinagoga, o culpado vou ser eu... meu tio já passou por isso com essa família, às vezes é melhor ir lá, apertar a mão, fingir que nada aconteceu.

O diagnóstico do seu tio foi, para minha surpresa, o de que, caso seu sobrinho partisse para a confrontação aberta, as pessoas com as quais ele estava tendo problemas poderiam não aparecer mais na sinagoga, e a culpa seria toda dele. Além disso, por mais irritantes que as pessoas sejam, todos anseiam por ver a sinagoga cheia, e lamentam o fato de que os serviços religiosos têm estado vazios. Uma das perguntas de seu tio foi "como andam os serviços das sextas-feiras?", à qual meu interlocutor respondeu: "vazios". 
Ninguém "quer ser o bode expiatório" (zondebok) nessas situações, diria o senhor a meu interlocutor. Isto foi determinante para que ele não devolvesse com ironia ou sarcasmo os constantes comentários desse pequeno grupo que alardeava suas viagens ao exterior e as recentes aquisições materiais, na sua opinião, com a intenção de se colocar acima dos outros judeus.

Há todo um cálculo para saber o momento propício para iniciar uma briga. Não tive nenhum contato com os judeus que, segundo meu interlocutor, se gabavam de suas aquisições materiais, mas (ainda segundo ele) eles tinham consciência de que o momento era favorável a este tipo de comentário, ou seriam advertidos por seus familiares caso não o fosse.

Muitas pessoas que conheci não frequentam a sinagoga regularmente. Estão sempre informadas, entretanto, sobre como está a frequência. Caso esteja baixa demais, podem ocasionalmente visitá-la para atender aos serviços e encontrar outras pessoas e famílias. O boca a boca é constante, há sempre informação sobre o que está havendo, quais famílias estão frequentando e quais "só comparecem em festas". Mesmo os judeus que optaram por abandonar completamente a vida na sinagoga (por terem se aborrecido com brigas passadas) parecem nutrir certa curiosidade em relação ao que se passa nos serviços, nas reuniões de jovens etc. Há nessa rede de comentários uma série de canais de informação.

E interessante examinar, nessas contendas, todos os desfechos aventados pelos atores como possibilidade de condução e solução dos conflitos. Embora estes não se atualizem, aparecem como desfechos possíveis; algo que poderia ter acontecido caso outra opção tivesse sido descartada.

Muitas de minhas conversas com meus interlocutores tratavam da forma como as coisas "poderiam ter sido":

[...] se ele estivesse disposto a brigar, como quando o avô dela era vivo, as coisas iam ser diferentes, eu acho [...]. Ele podia ter simplesmente dito a ela que seu avô deixava de cumprir suas obrigações com a comunidade para beber. Acho que ele preferiu ficar calado por isso [...]. Talvez ele tenha preferido fingir que não entendeu a insinuação, mas se tivesse falado do seu avô... [...]. Ou então porque não se fala assim dos mortos... não sei se ficaria bem para ele.

Quando os atores falam sobre questões familiares, aludem, eles próprios, aos desfechos possíveis, baseados, na maior parte das vezes, em suas observações dos resultados de contendas passadas. O que "poderia acontecer" é, neste caso, de grande interesse. Não importa que um lado seja considerado por alguns vitorioso, ou que o conflito esteja arrefecido, já que o "interessante" é que o outro lado poderia também ter vencido, ou a diver- 
gência ter prevalecido em lugar do apaziguamento dos ânimos. Toda a sorte de "palpites" sobre como a questão poderia ter sido conduzida vem à tona:

Ele preferiu desaparecer [da Sinagoga] [...]. Eu teria dito o que eu achava. Todo mundo ia ficar do lado dele, claro... Todo mundo ia ficar do meu lado, não ia? Imagine! E olha que foi ele quem organizou o retiro, e os tios dele, os avós dele, eram todos gente importante. Eu não teria ficado calado. Para mim, ele perdeu porque quis...

É importante chamar a atenção também para o que Bateson (1972:294) denominou "ruídos". Segundo ele, "tudo que não é informação, redundância, forma ou restrição - é ruído, a única fonte possível de novos padrões". Torna-se fundamental aludir às reflexões de Deleuze e Guattari sobre as diferenças entre as ordens "molar" e "molecular": a primeira correspondente às estratificações que dizem respeito a sujeitos, objetos e sistemas de referências, enquanto a segunda se refere à ordem dos fluxos, das intensidades, dos devires (cf. Guattari \& Rolnik 1988; Deleuze \& Guattari 1994). Os constrangimentos que se impõem às brigas familiares e às querelas, em geral em função de determinados tipos de resolução, com padrões éticos, estéticos e políticos relativamente delimitados, não colmatam por inteiro os fluxos e as intensidades envolvidos nas insatisfações.

Bateson fala em possibilidade de novos padrões. No entanto, ao invés de "padrão", neste caso, os termos "representações", "formas", "sistemas de referência" seriam mais apropriados. Tomemos a dissidência de alguns jovens que pretendem adotar um estilo de vida mais kosher, por exemplo; se assumimos que as formas não atualizadas não estão absolutamente perdidas, qual é o seu status de existência? Talvez as ordenações necessárias para que esse ou aquele conflito seja "resolvido" dispersem necessariamente possibilidades que podem trazer à tona novas formas. As possibilidades plausíveis não atualizadas continuam existindo enquanto possível. Nas palavras de Paul Veyne (1984:157), há "espaço [...] para objetivações não imaginadas". Sua existência não é detectável no plano das formas instituídas, mas pode se manifestar nos mais diversos modos; quando essa excrescência da autorregulação do sistema encontra outros "ruídos", estes podem objetivar-se em formas originais.

A "linha kosher" parece diretamente relacionada à resolução de uma série de questões que negligenciaram por completo as vontades de alguns. Ou, para se desfazer do indivíduo como categoria analítica, negligenciaram 
"forças de tendências mais ortodoxas", agenciadas na imanência biopolítica. Esta opção pelo descarte do "indivíduo" a priori se justifica na medida em que o "jovem" que encabeçava a "linha kosher" quando de minha primeira viagem apresentava-se como "mais para liberal"; reclamava da malícia de alguns em relação aos comentários feitos sobre a judaicidade e Hallakah e não parecia se importar com as questões de ordem que se impunham na organização dos serviços. Meses depois, contudo, estava profundamente descontente e já pensava em criar uma "nova linha": muitas de suas reclamações ecoavam as de outras pessoas, que aparentavam satisfação com o modo com que a tensão entre liberalidade e ortodoxia era conduzida.

A despeito de alguns se apresentarem como "liberais" ou "ortodoxos" e de esta informação ter grande relevância do ponto de vista descritivo, do ponto de vista analítico seria inocente crer que demandas classificadas como "liberais" e "ortodoxas" partem dos atores que se classificam como tais. Há uma disputa de forças que sempre é ordenada de maneiras distintas. Essas forças não se originam necessariamente dos indivíduos, já que eles próprios são atravessados por elas. Entender as motivações do jovem "mais para liberal" que se tornaria, meses depois, um dos "mais ortodoxos da comunidade" não passaria, neste ponto de vista, pela análise de um processo psicológico de influências internas e externas, mas sim por um exame de como determinadas forças são agenciadas. Esse mesmo jovem viria a me dizer:

[...] por mais que eles [alguns outros judeus] se digam ortodoxos, sempre acabam fazendo as coisas de um jeito que não é nem um pouco ortodoxo, para não arrumar briga com os outros. Para mim dá no mesmo, se você divide a mesma sinagoga em liberal e ortodoxa, ela é liberal. Tudo o que eu queria era uma comunidade [ortodoxa] como ela deveria ser. Mas a gente sabe que isso nunca vai acontecer, nunca.

Ele tende a crer que as soluções acomodadas para administrar a tensão entre tendências "liberais" e "ortodoxas" impossibilitam completamente a resolução de questões muito caras a ele pela via que considera mais correta: a adoção dos "costumes ortodoxos"; a tendência a evitar o conflito impede, para ele, que "se façam as coisas do jeito certo [op de juiste manier]". Ciente de que os arranjos acabaram por acomodar liberalidade e ortodoxia em um mesmo espaço (e.g. como na questão dos assentos mistos), o sentimento é de que, qualquer que seja a questão, ela será resolvida de maneira pouco satisfatória para seus desígnios. A exclusão dessas possibilidades, que para ele seria a solução ideal, viria a gerar certa dose de frustração (não só nele, como também em certos amigos), até que, em uma visita a Israel, 
Meu primo me mostrou que eu posso começar alguma coisa nova aqui. Não preciso aceitar o que os outros me impõem. Estou tentando me tornar o mais ortodoxo possível, Brian também, dentro dos limites dele. Rony quer participar. Podemos trazer famílias de Israel para cá e o governo ainda nos ajuda, pagando pra eles ficarem aqui. Para mim seria melhor, é isso que eu estou tentando fazer. [...] Já tem gente na Holanda interessada nisso, acho que pode dar certo.

Seu descontentamento encontrou reverberação em outras pessoas e experiências, enredando uma série de pessoas no Suriname e na Holanda na busca por uma cooperação com o governo de Israel, no sentido de trazer colonos que ajudariam a difundir o judaísmo ortodoxo no país. Daí a sua ideia de restabelecer o estilo de vida kosher no país.

A cada solução de uma questão ou conflito, certo descontentamento persiste. Pode esvanecer por completo, ou mesmo manifestar-se em pequenas reclamações. É possível, entretanto, que traga à tona novas formas, outros modos de ordenação, ou mesmo crie novas cisões; uma das contradições fundamentais nessa maneira de evitar conflitos é que um lado (ou ambos) sempre sai (saem), ainda que ligeiramente, insatisfeito. A explicação nativa mais comum sugere que essa insatisfação tem efeito cumulativo: no caso, ouvi que certas pessoas pararam de frequentar a Sinagoga porque essa ou aquela afronta foi a "gota d'água" (Druppel die de emmer doet overlopen).

Essa insatisfação, contudo, não é somente cumulativa, mas há relação com todo um campo de possíveis que não são completamente eliminados quando uma decisão é tomada. Em nome da trégua, um dos lados sai, em geral, insatisfeito por ter cedido à vontade do outro. O acúmulo gradativo dessas insatisfações (que vão desde uma dívida financeira até uma conduta considerada "errada" durante os serviços), além da reverberação destas com outras possibilidades de objetivação (como no caso da "Linha Kosher"), é justamente onde reside a formação de novos cismas, fenômenos e formas.

Essas "brigas" entre famílias aparecem, aqui, como fenômeno eminentemente positivo: ao mesmo tempo em que rompem relações, reafirmam laços familiares ou criam novos a partir da adesão de uma ou outra família ou pessoa a um dos lados do conflito. Essas "tomadas de partido", aproximações (e evitações), mobilizações de múltiplas concepções de família e seus limites (e de distinções entre "pessoal" e "familiar", já que a briga pode ser ou não uma questão de "família") são alguns dos efeitos observáveis do fenômeno 
das "brigas" entre famílias judaicas do país. Alianças são constantemente firmadas e rompidas, expectativas são criadas e descontentamentos latentes são atualizados através de manifestações observáveis, enquanto outros emergem de resoluções consideradas insatisfatórias por alguns. A distribuição local das dimensões do "dado" e do "construído" aparece na mobilização de categorias como "nome" e "sangue" para explicar comportamentos, qualidades pessoais ou afinidades. Muito mais do que uma ameaça à unidade, a "briga" surge como lugar privilegiado para investigar os processos através dos quais parentesco e afinidades são produzidos.

Recebido em 12 de agosto de 2013

Aprovado em 25 de julho de 2014

Thiago Niemeyer é professor colaborador do Programa de Pós-Graduação em Ciências Sociais da UFJF, com bolsa de pós-doutorado da CAPES. E-mail: <thiago.niemeyer@gmail.com>

\section{Notas}

${ }^{1}$ Para facilitar a leitura, utilizo itálico em palavras estrangeiras, exceto substantivos próprios, como de costume. Palavras em língua holandesa são assinaladas com itálico e sublinhado se forem substantivos comuns, e só com sublinhado se substantivos próprios.

${ }^{2}$ A palavra "sefardita" tem origem no termo hebraico Sepharad, que designa a Península Ibérica.

${ }^{3}$ O termo "asquenazita" vem de "ashkenaz", denominação do hebraico medieval para a atual Alemanha.

${ }^{4}$ Os judeus residem, em sua maioria, na capital Paramaribo, embora haja algumas exceções. Ad de Bruijne tem, pelo menos, dois estudos (ambos em língua holandesa) sobre demografia e os padrões de ocupação da cidade, que mencionam - ainda que lateralmente e de maneira muito breve - a presença judaica na capital surinamesa (ver De Bruijne 1976 e De Bruijne \& Schalkwijk 1997).

${ }^{5}$ Dia de descanso semanal no judaísmo. Observado do pôr do sol de sexta-feira ao pôr do sol de sábado. 
${ }^{6}$ Carsten chama a atenção para o fato de que "antropólogos que trabalham na Índia e em Papua (Nova Guiné), entre outros lugares, adotaram substância como forma de compreender o parentesco em termos mais processuais, observando como pessoas são constituídas através de suas relações umas com as outras" (Carsten 2004:109)

${ }^{7}$ Os nomes de famílias que aparecem ao longo do texto foram substituídos por letras (A, B, C, G, S etc.) e os que aparecem por extenso são fictícios, o mesmo ocorrendo com os prenomes.

${ }^{8}$ Termo utilizado para o conjunto de leis da religião judaica.

${ }^{9}$ Expressão do Srnan Tongo, crioulo local. Termo usado para designar herança mista.

${ }^{10}$ Termo utilizado para mulheres com as quais se tem relação fora do casamento.

${ }^{11}$ Parece significativo que entre os judeus sefarditas de Curaçao, até a década de 1940, fosse comum a prática de os homens manterem concubinas, as keridas. Os filhos dessas uniões eram conhecidos como yu de judio - filho de judeu - e os netos, nieto di judio - neto de judeu (Abraham-Van der Mark 1993:46). Ao contrário do caso surinamês, no entanto, as crianças nascidas fora do casamento pertenciam sempre à religião da mãe, em geral o catolicismo romano (Abraham-Van der Mark 1993:46). Dizer que alguém tem sangue judeu (tin sanger di judio) - não sendo filho ou neto, mas relacionado de alguma forma - é uma maneira de destacar determinadas qualidades, como as de bom negociante ou alguém que aprende línguas com facilidade.

${ }^{12}$ O termo Mahamad alude, historicamente, ao conselho judaico local, também conhecido como "os regentes". Para maiores informações sobre a história do Mahamad e seus processos decisórios, ver The Jewish Nation in Surinam: Historical Essays (1982), de Robert Cohen; Creole Jews (2010), de Wieke Vink. Há referências importantes também em outros trabalhos de Robert Cohen (1982a, 1991) e Vink (2001).

${ }^{13}$ Literalmente traduzido como "árvores genealógicas". No contexto etnográfico em questão, contudo, esses artefatos podem adquirir as mais diversas formas e desempenham um papel importante na produção da ancestralidade e do parentesco. Não poderei, contudo, desenvolver o material obtido em campo no presente artigo, sobretudo por questões de espaço.

${ }^{14} \mathrm{O}$ termo kosher refere-se ao conjunto de leis alimentares do judaísmo. 


\section{Referências bibliográficas}

ABRAHAM-VAN DER MARK, Eva. 1993. "Marriage and concubinage among the Sephardic merchant elite of Curaçao". In: Janet Monsen (org.), Women and change in the Caribbean: a pan Caribbean perspective". Kingston: Indiana University Press. pp. 38-49.

BATESON, Gregory. 1972. Steps to an ecology of mind. San Franciso: Chandler Pub.

CARSTEN, Janet. 2004. After kinship. Cambridge: Cambridge University Press.

__ \& HUGH-JONES, Stephen (orgs.). 1995. About the house: Lévi-Strauss and beyond. Cambridge: Cambridge University Press.

COHEN, Robert. 1991. Jews in another environment: Surinam in the second half of the eighteenth century. Leiden: E. J. Brill.

- (org.). 1982a. The Jewish nation of Suriname: historical essays. Amsterdam: Emmering Publishers.

- 1982b. "Patterns of marriage and remarriage among the Sephardi Jews of Surinam, 1788-1818". In: Robert Cohen (org.), The Jewish nation of $\mathrm{Su}$ riname: historical essays. Amsterdam: Emmering Publishers. pp. 114-128.

COMERFORD, John. 2003. Como uma família: sociabilidade, territórios de parentesco e sindicalismo rural. Rio de Janeiro: Relume Dumará.

DE BRUIJNE, Ad. 1976. Paramaribo: stadsgeografische studies van een ontwikkelingsland. Bussum: Romen. - \& SCHALKWIJK, Aart. 1997. Van Mon Plaisir tot Ephraïmszegen: welstand, etniciteit en woonpatronen in Paramaribo. Amsterdam: AGIDS University of Amsterdam. DELEUZE, Gilles \& GUATTARI, Felix. 1994. Mil platôs: capitalismo e esquizofrenia. Rio de Janeiro: Ed. 34.
DOMINGUEZ, Virgínia. 1986. White by definition: social classification in Creole Louisiana. New Brunswick: Rutgers University Press.

GUATTARI, Felix \& ROLNIK, Suely. 1988. Micropolítica: cartografias do desejo. Petrópolis: Vozes.

LÉVI-STRAUSS, Claude. 1982. The way of the masks. London: Johnatan Cape.

STRATHERN, Marilyn. 1994. "Parts and wholes: refiguring relationships". In: Robert Borofsky (ed.), Assessing cultural anthropology. New York: McGraw-Hill. pp. 204-217. · 1996. "Cutting the network". The Journal of the Royal Anthropological Institute, 2(3):517-535.

VEYNE, Paul. 1984. Como se escreve a história; Foucault revoluciona a história. 4. ed. Brasília: Editora Universidade de Brasília.

VINK, Wieke. 2010. Creole Jews: negotiating community in colonial Suriname. Leiden: KITLV Press. . 2001. "Over migranten, suikerplanters, Joodse kleurlingen en religieuze tolerantie: De Joodse ervaring in $\mathrm{Su}$ riname". OSO, 20:18-42.

WAGNER, Roy. 1991. "The fractal person". In: Marilyn Strathern \& Maurice Godelier (orgs.), Big men and great men: personifications of power in Melanesia. Cambridge: Cambridge University Press. pp. 159-173.

WESTON, Kath. 1992. Families we choose: lesbians, gays, kinship. New York: Columbia University Press. 


\section{Resumo}

O artigo a seguir trata, do ponto de vista etnográfico, das "brigas" (familievete/ vechten) entre famílias judaicas em Paramaribo, capital do Suriname. A "briga" é entendida, no contexto etnográfico em questão, como momento não apenas de ruptura, mas de surgimento de novas alianças através da "tomada de lados" (partij kiezen /deel te nemen). Parentelas não atualizadas são acionadas, e pessoas se tornam "parentes" (relatief), da mesma forma que certas relações arrefecem, distanciando os sujeitos e mudando a forma de se referir a estes. As "brigas", além disso, trazem à tona a distinção nativa entre o dado e o construído: alguns, por se omitirem nessas contendas ou tomarem outro "lado", tornam-se parentes apenas de "sangue" (bloed) ou "nome" (naam). Buscar-se-á, dessa forma, explorar a dimensão positiva dessas "brigas", entendendo-as não apenas como provocadoras do que chamaríamos "rompimento", mas produtoras de novas alianças e obrigações. Palavras-chave Família, Caribe, Suriname, Judaísmo, Relacionalidade.

\section{Abstract}

The article is an ethnography of the "feuds" (familievete/vechten) between Jewish families in Paramaribo, Suriname. In this ethnographic context, the "feud" is understood not only as a moment when alliances are broken, but also as an event where new alliances arise, since individuals have to "choose sides" (partij kiezen/deel te nemen). Nonactualized kinship relations thus appear, as people become relatives (relatief), while other relations lose their intensity, rendering people apart and changing the terms they use to refer to each other. The "feuds" bring up local distinctions between "biological" and "social": some individuals, by choosing not to take part in these disputes or choosing a different "side", become merely "blood" (bloed) or "name" (naam) relatives. The focus is therefore on the positive dimension of "feuds", which are not only the cause of a "rupture", but active producers of new relations and obligations.

Key words Family, Caribbean, Suriname, Judaism, Relatedness. 